\title{
A Player Bigger Than Its Size: Finnish Bioeconomy and Forest Policy in the Era of Global Climate Politics
}

\author{
Tero Toivanen
}

\subsection{Introduction}

During the last few decades, the bioeconomy has become a key feature in framing the transition to a sustainable future. Transnational economic organisations and many countries have drawn up ambitious bioeconomy strategies. Recently, some governments in industrialised countries have adopted these strategies in order to strike a path that goes beyond the fossil economy (Meyer 2017). These strategies represent bioeconomy as a sustainable solution that mitigates climate change and other environmental problems as well as creating the next generation of sustainable products and fostering green economic growth. Thus, bioeconomy incorporates a remarkably wide set of ideas and economic activities under one inspiring and highly optimistic umbrella term (Birch 2006; Birch and Tyfield 2013; Bugge et al. 2016).

T. Toivanen $(\bowtie)$

BIOS Research Unit, Helsinki, Finland e-mail: tero.toivanen@helsinki.fi 
Bioeconomy is particularly important in countries with a large forestry sector. Forests are one of the most promising resources for societies that are searching for ways to replace the fossil economy. Simultaneously, the flexibility of the concept enables the forest industry to reframe its traditional industrial operations in new, greener terms: in the blink of an eye, pulp factories become "biorefineries" or "bioproduct factories". Finland is a case in point. During the last decade, Finland has provided a platform for a successful bioeconomic imaginary (Goven and Pavone 2015). After decades of decline, this imaginary has significantly contributed to a development that has relocated the traditional forest industry at the heart of the Finnish national political economy. These bioeconomic developments have prepared the ground for a new forest policy regime (see Donner-Amnell et al. 2004; Kotilainen and Rytteri 2011), the bioeconomy regime. As a result, the forest bioeconomy emerged as an important, if not the most important, policy of the Finnish centre-right government that was in power between 2015 and 2019.

However, a novel scientific factor now poses a challenge to the image of sustainability that shrouds the forest bioeconomy. The rapid climate mitigation targets that were put in place in the wake of the Paris Climate Agreement not only entail radically slashing emissions from fossil fuel but also removing carbon dioxide from the atmosphere. The world is to achieve carbon neutrality around mid-century, with developed countries expected to reach carbon neutrality a lot earlier. Finland is to be carbon neutral as close as possible to 2030 (FCCP_Finnish Climate Change Panel 2018).

The world's forests have a crucial role to play in this global and national "Herculean task" (Rockström et al. 2017): as part of landbased ecosystems, forests are the only functioning carbon sinks that can increasingly remove carbon from the atmosphere. Thus, the best way of achieving rapid climate mitigation is to develop global carbon sinks by stopping deforestation, significantly reducing harvesting and implementing reforestation projects. Obviously, if the role of forests is framed within these terms, the politics of carbon sinks at the global level have enormous political, economic and social importance in countries with large forestry sectors, such as Finland. 
The issue of carbon sinks burst onto the stage as part of the Finnish public debate soon after the bioeconomic imaginary had successfully repositioned the forest sector at the core of national political economy. In a short period of time, the world of Finnish forestry seemed to have been turned upside down: the bioeconomy plans, which had hitherto sailed along in fair winds, suddenly came to be questioned. Finnish climate and forest researchers delivered an unpleasant message, which was underscored by the tightening of EU climate policies: Finland's bioeconomy strategies - which were based on increasing the rate at which forests were harvested and, thus, reducing the size of forest carbon sinks-would certainly not be able to mitigate climate change in the time available.

In this paper, I study how the results of scientific research on the role of forests in climate change mitigation challenged the Finnish bioeconomy regime. I analyse the key developments of a four-year debate from 2015 to 2019 on forest carbon sinks with a special focus on how actors closely related to the forestry sector reacted to the messages brought up by researchers. I rely on frame analysis, which has been widely practised in media studies, to understand how journalism creates and reinforces certain ideas in society (e.g. Entman 2007; Harjuniemi 2019). Framing collects certain aspects of a perceived reality and reformulates them as a narrative that promotes a particular interpretation. Frames introduce and enhance the importance of certain ideas in public discussion and activate "schemas" that encourage target audiences to think, feel, discuss and decide in a particular way (Entman 2007, pp. 164-165). In the case of Finnish bioeconomy, framing the public debate has significantly contributed to forming and legitimising historical forest policy regimes (see also Peltomaa 2018).

Finland represents an important case study in global climate and bioeconomy politics. Its globally influential forest industry means that it can obtain a greater role in global climate politics than its small size might suggest and, thus, it can be considered as an influential small and medium-sized power (Eloranta et al. 2018) in global political economy. The role of forests in climate change has been debated widely in Finland. This makes the Finnish case interesting in an international context: How has a novel scientific message and the tightening of EU climate regulation 
challenged the existing forest bioeconomy regime? How did the regime respond and how has it attempted to defend its interests and power?

This paper proceeds as follows. In the first section, I analyse the special features of the Finnish forest bioeconomy regime. In the second section, I describe in detail how the issues of forest carbon sinks and new EU climate regulation have challenged the bioeconomy regime. In the third section, I offer an analysis of the three-phase development that occurred in Finnish public debates about carbon sinks between 2015 and 2019. In the last section, I discuss the international political importance of the Finnish bioeconomy debate.

\subsection{Finnish Bioeconomy as a Forest Policy Regime}

Forestry has had an enormous impact on the history of Finland. The turns in the political economy of forestry have been closely related to the transformations of society as a whole. Previous research has analysed Finnish forestry in the context of historical forest policy regimes (Donner-Amnell et al. 2004; Kotilainen and Rytteri 2011). Historically, forest policy regimes have consisted of long-term, quasi-permanent, social, political, economic and cultural arrangements that underlie governmental actions (Kotilainen and Rytteri 2011). Regimes have changed over time: from the nineteenth-century pre-industrial regime and the industrial regime during the two world wars to a regime that from 1970s onwards has incorporated some aspects of environmental sustainability (ibid.; Kröger and Raitio 2017).

Despite these historical transformations, some things have remained the same. The symbiosis between private forest owners and the forest industry has created the social, political and economic basis for the long-term development of Finnish forestry. Whereas forest industry has been responsible for production, private forest owners have taken care of planting, growing and marketing wood. The social power of both actors has been enforced through the establishment of central associations: the Finnish Forest Industries and the Central Union of Agricultural Producers and Forest Owners (MTK). Furthermore, state policies have 
been harnessed in multiple ways to support the industry by organising funding, investing in infrastructure, drawing up trade policies and encouraging applied scientific forest research (Siiskonen 2007; Kröger and Raitio 2017).

Finnish bioeconomy is so fundamentally connected to the utilisation of the country's forest resources that Finnish bioeconomy is forest bioeconomy. As such, bioeconomy in Finland marks a potential beginning for a new forest policy regime. One promising way to analyse the material development of the bioeconomy is the opposition between an expansion frame (which means that an industrial regime, despite all of the green rhetoric and policies, continues to organise production in traditional extractivist terms) and a transformation frame (policies that set in motion a sector-wide low-carbon, sustainable transition).

Finnish bioeconomy emerged at a particular historical moment. On the thresholds of the 2008 global economic crisis, Finland experienced a twofold industrial setback. First, and this already applied before the financial crisis, the traditional chemical forest industry, the long-time core of the export-led national economy, was facing a downturn. Second, at the end of the 2000s, a successful Finnish high-tech sector came tumbling down when its cornerstone, the mobile phone company Nokia, ran into deep problems and shut down its landmark mobile device division.

In these historical conditions, the idea of bioeconomy started to gain attraction. The six-party coalition government that was in power between 2011 and 2015 was the first to mention the idea of bioeconomy and did so in its 2011 manifesto. In 2014, the first official bioeconomy strategy for Finland was published, and the centre-right government that was in office between 2015 and 2019 eventually adopted bioeconomy as the core of its approach. As a result, attention in Finnish political economy shifted from the promise of a network society to the promotion of a deeper use of Finland's natural resources. This led to the introduction of a new techno-economic framework, the bioeconomy regime, aimed at industrial renewal and which combines the traditional forestry sector with the promise of innovations and bioproducts. 
Recently, Ahlqvist and Sirviö (2019) have argued that settling the tension between urban and rural areas constitutes a material condition for a successful bioeconomy regime. The industrial restructuring that took place during and after the 2000s hit the Finnish periphery hardest. To solve the problems of rural areas, the advocates of the bioeconomy promised "new economic dynamics to emerge throughout the state space, fostered by new investment projects and state subsidies designed to update infrastructures in the peripheral regions" (ibid., p. 403). Simultaneously, the bioeconomic imaginary also appealed to the advocates of urban-led development: whereas the countryside would continue to play the role of resource periphery, the high-tech side of the bioeconomy fit well into the high-skilled and educated imaginary of the urban bourgeoisie. In addition, when the bioeconomy initiative also promises solutions to climate change, this leads to a potential political compromise in which "everyone wins".

The implementation of bioeconomy strategies depends on the election of a supportive government. Finnish bioeconomy has always been a project of the Centre Party, a party with its electoral base in rural areas. An interesting anecdote associated with Finnish politics is the fact that bioeconomy is strongly associated with the former leader of the Centre Party, Juha Sipilä, who was the prime minister from 2015 to 2019. Before the 2015 parliamentary elections, Finnish media was enthralled by this successful businessman who had jumped into politics. The future prime minister drove around the rural periphery of North Finland with his wood-burning carbon monoxide car and promoted bioeconomy as a key to a sustainable future in Finland. Thus, the urban-rural contradiction was also settled in this political character.

In 2015, Finnish bioeconomy finally had its moment when the Centre Party and the right-wing National Coalition party, which is associated with the urban bourgeoisie, formed a government. The election of the new centre-right government provided the Finnish forest sector reason for celebration after decades of uncertainty. The positive atmosphere culminated in the decision to build the Metsä Group's Äänekoski "bioproduct factory", the biggest investment in the history of Finnish Forest Industry. The factory was strongly supported by a wide political 
spectrum. Bioeconomy was booming, and the new centre-right government declared bioeconomy as its most important (by net monetary investment) priority project.

Nevertheless, the Finnish bioeconomic imaginary has also faced criticism. Before the negative effects of these bioeconomy plans on the climate were fully understood, the left-wing parties, the Social Democrats, the Left Alliance and the Greens were sceptical about the bioeconomy. Furthermore, environmental NGOs criticised the possible negative impact (e.g. loss of forest biodiversity) associated with bioeconomy (see, e.g., FANC-The Finnish Association for Nature Conservation 2014). Thus, critical voices identified forms of "green washing" in the bioeconomy discourse. Criticism has also been directed at the fact that the majority of the bioeconomy (in terms of volume) remains in traditional industrial products, namely paper and pulp-a fact that would support the continuity of the expansion frame over any supposed move towards a transformation frame.

Another important matter that defines the Finnish bioeconomy regime is forest bioenergy. Forest bioenergy composes one quarter of the total energy produced in Finland. In the renewable energy sector, forestbased biomass represents $74 \%$ of the energy produced, thus making it the most important "renewable" source of energy (for the problem of counting bioenergy as renewable see Harjanne and Korhonen 2019). Despite the fact that bioenergy is often viewed as a renewable, it causes significant greenhouse gas emissions (see Searchinger et al. 2018; Letter from Scientists 2018; Vadén et al. 2019).

\subsection{A Twofold Threat to the Regime: Carbon Sinks and EU Regulation}

The vision of Finnish bioeconomy as sustainable started to crack when the bioeconomy regime was challenged by climate science. The Finnish bioeconomy strategy (2014) and the bioeconomy plans associated with it involved increasing forest harvesting. In addition, the centre-right government's Energy and Climate Strategy (Huttunen 2017) was also based on increasing the annual harvesting of forests-from 65 million 
to a record-breaking 80 million cubic metres. As mentioned above, increasing harvesting - the material basis of the forest bioeconomyfaced very little criticism when the Finnish bioeconomy strategy was first introduced. Thus, the cornerstones of Finland's "actually existing forest bioeconomy" (the chemical forest industry and bioenergy) were generally accepted as environmentally sustainable solutions.

For quite some time, therefore, the use of forest biomass had been considered sustainable and was even promoted for climate reasons: harvested forests were to be replaced by new forest growth, which would soak up the carbon emissions associated with harvesting. This argument promotes forest-based bioenergy, for example as an attractive and renewable replacement for fossil fuel. However, the situation looks different when the rapid time span of climate mitigation is taken into consideration. Harvesting decreases the size of forest carbon sinks, and when wood is used for short-term products, such as paper, pulp or bioenergy, carbon is released immediately or relatively quickly into the atmosphere. New boreal forests take decades, in some cases even more than a century, to store the carbon released by harvesting (e.g. Sievänen et al. 2014; Soimakallio et al. 2016; Public Statement 2017). Importantly, it takes more than two decades for newly planted forests to even start beginning to store significant amounts of carbon. If there is pressure to increase harvesting, this makes short-term carbon neutrality targets even harder to achieve. These facts were brought to the public's attention from 2014 onwards by climate researchers, the FCCP and, in March 2017, by a public statement signed by 68 Finnish researchers (see Public Statement 2017). Together, this evidence questioned the sustainability of the bioeconomy regime.

However, the issue of carbon sinks was not the only black cloud that was gathering above the Finnish bioeconomic imaginary. The EU was also reconsidering the principles behind its climate policy, and the regulation of how member states use their lands and forests. The EU "land use, land use change and forestry" regulation (LULUCF) draws up binding commitments for each member state to regulate its emissions from land use. It is the latest set of regulations in the EU climate and energy policy framework, and LULUCF policies are to be enshrined in EU law by 2021. 
This upgrading of LULUCF monitoring made land use emissions an important political issue, especially for member countries with large forestry sectors. In order to monitor member states' land use, a "forest reference level" (an estimate of annual average net emissions from managed forest land) was set. Eventually, the EU chose the period between 2000 and 2009 as the reference level. In Finland, the reference level was viewed as unfavourable because the decline of the chemical forest industry had led to reduced harvesting during the 2000s. The planned increase in harvesting from 2015 onwards would significantly decrease the size of carbon sinks and increase net emissions from the land use sector. Finland pointed out that the proposed reference level treated the Nordic member states unequally: following historical harvesting levels placed Sweden into a more favourable position. During the whole LULUCF negotiation process, the official line of the centre-right government was that member states, not the EU, should have the final say on how forest biomass is used.

Consequently, and rather unpredictably, the Finnish bioeconomy regime faced challenges on two fronts. On the one hand, this led forestry actors to engage in public discussions about carbon sinks. On the other, it led the interests of Finnish forestry to be defended at the EU level. In the next three sections, I analyse the key public discursive strategies that different forestry actors used to frame the discussion about the role of forests in climate mitigation in order to support the existing bioeconomy regime. By forestry actors, I mean organisations with close ties to the interests of Finnish forestry, mainly the representatives of the Finnish Forest Industries, the Central Union of Agricultural Producers and Forest Owners and the Central Party. I distinguish between three chronological periods in the public debate: the regime under shock, the battle in the $\mathrm{EU}$ and stabilisation of the regime.

\subsection{The Regime Under Shock}

A public statement, undersigned by 68 Finnish researchers, released in March 2017, caused a public "storm" (Hukkinen et al. 2017) that shocked the bioeconomy regime. There was nothing fundamentally 
new in the substance of the statement: it merely stated that increasing harvesting caused a threat both to carbon sinks and to forest biodiversity-both facts had already been acknowledged in several scientific publications. This time, however, the message was brought to the public not by individual researchers or by the FCCP, which already had established role in Finnish climate science communications, but collectively by researchers from a broad spectrum of environmental studies.

The shockwaves sent through the regime led advocates of the bioeconomy regime to put forward a set of aggressive arguments. ${ }^{1}$ However, the researchers' statement provoked these sentiments even before it had been published. At a time when the statement was still circulating among researchers with the aim of gaining signatories, it was provided to the media and was dismissed by forestry actors. For example, Katri Kulmuni, the then vice-chair, and later leader of the Centre Party, referred to the authors and potential signatories of the statement as "unpatriotic". When the statement was published, a leader of the Central Union of Agricultural Producers and Forest Owners (MTK) dismissed it as "a political pamphlet" that "ignores scientific facts" and focuses on a "narrow perspective and a short time period". One forestry leader wanted to teach researchers a lesson about the growth of forests by sending them to "a course where they can be taught how carrots grow". Another leader chose even more innovative phrasing by calling the statement "forest Trumpism" and recommending that the "researchers, who published the clearly political pamphlet, should stop prattling and grab a chainsaw instead". Maaseudun Tulevaisuus, a newspaper closely associated with the forestry sector, questioned where the researchers who had facilitated and signed the statement received their funding.

Although the statement made carbon sinks an unavoidable issue in Finnish climate politics, it was also used to create the impression that two camps of researchers existed with different opinions on the role of forests in climate mitigation. In practice, this was not the case. Researchers

\footnotetext{
${ }^{1}$ The statements analysed here are drawn from forthcoming wider analysis of the Finnish carbon sink debate. The arguments appeared in three major Finnish mass mediums, Yleisradio (Finnish National Broadcasting Company), Helsingin Sanomat (the biggest daily newspaper) and Maaseudun Tulevaisuus (a newspaper closely associated with the Centre Party and the forest industry). Katri Kulmuni's statement is from her Facebook post (16 March 2017).
} 
are clearly unanimous about the key fact that increasing harvesting will reduce carbon sinks during the period in which climate mitigation can still have an impact. However, political differences exist when people do not accept climate politics or the rapid timetable for mitigation as a steering framework for political decisions or scientific inquiry. Nevertheless, forestry actors focused their attention on the legitimacy of the statement despite the fact that the same arguments about carbon sinks and forest use had already been expressed in several research publications, including those by the Finnish Climate Change Panel (FCCP 2015) and the European Academies' Science Advisory Council (Aszalós et al. 2017), as well as a public letter signed by 800 European scientists (Letter from Scientists 2018).

During this period, the bioeconomy regime set aside its internal differences and organised a front against a common threat. In the beginning of the period characterised by the centre-right government, things had been different: forest actors debated openly about how and who should be able to use scarce forest resources. In 2015, the forest industry claimed that the higher value-adding chemical forest industry would face resource shortages if the share of forest-based bioenergy were to be increased. In contrast, the forest owners (MTK) provided reassurances that there was enough wood in Finnish forests to implement all of the planned bioeconomic strategies. Simultaneously, the credibility of the centre-right government's bioeconomy target, 100,000 new bioeconomy jobs, was openly questioned by forestry actors. These opinions were an expression of an internal struggle over the bioeconomic monetary flows promised by the new government.

\subsection{The Battle in the EU}

In June 2016, the EU Commission presented the LULUCF legislative proposal. In principle, it followed contemporary scientific findings about the role of forests in climate mitigation, and, as such, it was directed at instantly blocking forest policies that led to increased harvesting and reducing the size of carbon sinks. In Finland, the forest bioeconomy regime viewed the proposal as a declaration of war. When the forest 
regime realised that Finnish lobbying in the EU had failed terribly, it began to search for the "guilty parties". Fears were expressed that the proposal would clash with the country's bioeconomy plans and forestall investments in new pulp factories.

A new front was built. One member of the European Parliament, who had been engaged deeply in the LULUCF process, declared that "a spirit of Winter War is needed" to amend the Commission's proposal. The bioeconomy regime started a campaign which, in the history of Finnish EU lobbying, can be viewed as "exceptionally voluminous". Most Finnish members of the EU Parliament, the centre-right government and different actors from the forestry sector used all of their power to influence the situation in the name of the "interests of the Fatherland" (as it was often portrayed in the media). In addition, political alliances were sought from other member states; Sweden, with its large forest sector, being the most important. One year later, in July 2017, despite all of the war rhetoric, the European Parliament Committee on the Environment (ENVI) voted for even tighter regulation of the LULUCF sector. ENVI entailed annual surveys of the trajectory of member states' carbon sinks and restricting unfavourable forest use immediately, not at some point in a possible future-again, a position that was in line with scientific consensus on the role of forests in climate mitigation.

This was followed by a final (and successful) round of lobbying by Finland. In September 2017, the European Parliament finally approved the LULUCF legislation; however, Finland, supported by other countries with large forestry sectors, such as Sweden, had lobbied successfully for a crucial change to the LULUCF proposal. The original proposal's focus on immediate change to forest use and carbon sinks was altered in favour of a concentration on the long-term perspective, which left the door open to immediately increasing harvesting in certain member states if carbon sinks were expanding in the EU as a whole. The bioeconomy regime celebrated the vote as a historical victory. The CEO of Finnish Forest Industry, interviewed by Yleisradio (the Finnish Broad Casting Company, 13 September 2017), expressed gratitude for the successfully conducted "national endeavour" and described the political importance of the LULUCF decision for the world in honest terms: "The world is not getting better here. But we are now blocking decisions that would be 
totally unreasonable for Finland and bad for our economic development and forest industry".

\subsection{Stabilising the Regime}

After the battle had been won at the EU level, a more nuanced discussion on behalf of the forestry regime followed. Forest actors strived to stabilise the faltering bioeconomy regime. Interestingly, during this period, the concept of bioeconomy appears less in public discussion. Further research is needed to analyse why this happened, but the focus of the forest debate obviously shifted from abstract promotion of the bioeconomic imaginary to more concrete and conflictual issues that eventually constituted the future of the bioeconomy regime. In the wide spectrum of public debate that took place between 2017 and 2019, three dominant discursive strategies continued to confront the scientific arguments on the role of forests in climate mitigation. Forestry actors focused on using the frame of sustainable development, emphasised the special characteristics of Finland as the land of the forest industry and drew attention to the growth of forests.

First, in answer to the scientists' point about ecological sustainability, forest actors emphasised that it was only one aspect of a broader sustainability perspective and that it was essential that economic and social factors were provided with an equal level of recognition in the future of Finnish forestry. Thus, the forestry actors presented the famous three pillars of sustainability (ecological, social and economic development) as equally important. In contrast, the researchers concerned about the diminishing size of carbon sinks argued that the short period available for climate mitigation meant that planetary limits needed to be prioritised and that social and economic development would have to be adjusted accordingly (see Hukkinen et al. 2017).

A second strategy is familiar from any discussion about climate change: the smallness of a country is held as a justification for a moderate level of climate action, which, after all, is a global problem that no country can solve alone. Thus, the argument goes, the question about 
Finnish forest carbon sinks is irrelevant in the bigger picture when countries such as China and India are largely responsible for climate change. Furthermore, forest actors stressed that Finnish forest bioeconomy was the most sustainable in the world and that if harvesting were to be restricted, the production of bioeconomy products (i.e. pulp and paper) would be relocated to countries with less stringent environmental regulation. Thus, the production of bioeconomy products in Finland was framed as an act of climate mitigation.

Third, and most importantly, forestry actors focused the carbon sink discussion on the expansion of forests. As stated above, a favourable decision on the LULUCF regulation was extremely important for Finland. In its final form, LULUCF does not penalise countries in which increased harvesting is causing an annual decrease in the size of their carbon sinks if carbon sinks are increasing annually throughout the EU as a whole and in all member countries in the long term.

During the period in which the LULUCF legislation was being drawn up, the Finnish Natural Resource Institute remodelled the growth of Finland's forests. At the end of 2018, the Institute published new results demonstrating that forests in Finland were expanding significantly. This pushed up the previous estimate of "economically sustainable" harvesting (and which enabled harvesting to be increased) if the immediate threat of a loss of carbon sinks caused no ramifications. This has been the case since the implementation of the LULUCF regulation. In addition, the estimate indicated that forest carbon sinks had expanded dramatically. Between 2015 and 2024, for example, forest carbon sinks were now said to have grown from 16.5 megatons $(\mathrm{Mt}) \mathrm{CO}_{2}$ to close to $40 \mathrm{Mt} \mathrm{CO}_{2}$; these figures put the carbon sinks at more than twice the size estimated two years earlier. The unexpected increase in growth was said to be a result of better forest management, healthier saplings and the effects of climate change.

These results were interpreted by the bioeconomy regime primarily as evidence of good forest management. Thus, now that forests had grown much more than expected, there was room for increased harvestingin other words, the regime could continue with the expansion frame without complying with the transformation frame. The estimates produced by the Forest Institute and its interpretation of the bioeconomy 
regime did not satisfy climate scientists. In February 2019, the Finnish Climate Change Panel published a report (FCCP 2019) that provided five different models of both the growth of Finland's forests and the development of carbon sinks in the country. The report found that only one model supported the idea that forests could be simultaneously harvested and preserved as carbon sinks. This model was known as the MELA model and was the one that the Forest Institute (LUKE) was using. Furthermore, the Climate Panel report stated that all of the other models demonstrated that increased harvesting would lead carbon sinks to decrease in size and that this would continue to be the case for decades to come. For this reason, the Panel recommended that "the cleverest thing would be to decrease the level of harvesting". This case demonstrates just how complicated, technical and, perhaps, political, estimating climate impact can be.

\subsection{Conclusion}

When public awareness of the multifarious environmental crisis increases, and climate regulation tightens, it seems obvious that the sustainability of the bioeconomy imaginary will be critically evaluated. This occurred in Finland rather suddenly when climate scientist questioned the path set by the regime and, at the same time, the EU aimed to draw up a more ambitious form of climate regulation. The reaction by Finnish forestry was forceful. The bioeconomy regime engaged aggressively with public debate and harnessed all of its power to influence EU climate regulation in the interests of the Finnish forestry sector. Towards the end of the period under analysis, the strategies of forestry actors became more nuanced and focused on the growth of Finland's forests.

In global climate politics, "a small and medium-sized power" like Finland, can gain a bigger role than its position in world politics might imply. The capability of Finland to effectively lobby at the EU level for forest policies that served the interests of its forestry sector complicates the achievement of ambitious climate targets in Finland and in the rest of Europe. Importantly, it is impossible to rule out that this will have a 
major impact on the climate: if Finland is capable of lobbying for international policies that enable increased forest harvesting in a period in which rapid climate mitigation is essential, what would prevent other countries from following suit?

I have analysed the evolution of bioeconomy in Finland as a novel forest policy regime. The bioeconomic imaginary relocated the traditional forestry sector with its strong green image to the core of Finnish society. It is too early to assess the resilience and future of this relatively new forest regime. However, the case of Finnish bioeconomy demonstrates how the success of the bioeconomic imaginary in national terms requires favourable political conditions; this makes the bioeconomy regime dependent on existing political trends. The approach of the new Finnish left-green government, which was formed in May 2019, to forest bioeconomy and climate politics is substantially different to the policies adopted by the centre-right government in 2014. At this time, the bioeconomy was booming and nobody, with the exception of specialists from this field, had even heard of "carbon sinks". If the bioeconomy imaginary loses national ground when the political winds turn, the attractiveness of the transnational bioeconomy might also weaken relatively quickly. For this reason, a more sophisticated analysis of the political economy of bioeconomy is needed: critical research should evaluate which tendencies of the bioeconomy project, if any, are actually sustainable at the international level in the face of changing political conditions.

\section{References}

Ahlqvist, T., \& Sirviö, H. (2019). Contradictions of Spatial Governance: Bioeconomy and the Management of State Space in Finland. Antipode, 51(2), 395-418.

Aszalós, R., Ceulemans, R.J., Glatzel, G., Hanewinkel, M., Kakaras, E., Kotiaho, J., et al. (2017). Multi-functionality and Sustainability in the European Union's Forests, EASAC Policy Report (No. 32). Halle (Saale): European Academies Science Advisory Council (EASAC). https://easac. eu/fileadmin/PDF_s/reports_statements/Forests/EASAC_Forests_web_com plete.pdf. Accessed 30 Sept 2020. 
Birch, K. (2006). The Neoliberal Underpinnings of the Bioeconomy: The Ideological Discourses and Practices of Economic Competitiveness. Genomics, Society and Policy, 2(3).

Birch, K., \& Tyfield, D. (2013). Theorizing the Bioeconomy: Biovalue, Biocapital, Bioeconomics or... What? Science, Technology, \& Human Values, 38(3), 299-327.

Bugge, M., Hansen, T., \& Klitkou, A. (2016). What Is the Bioeconomy? A Review of the Literature. Sustainability, 8(7), 691.

Donner-Amnell, J., Lehtinen, A., \& Saether, B. (2004). Comparing the Forest Regimes in the Conifer North. In A. Lehtinen, J. Donner-Amnell \& B. Sateher (Eds.), Politics of Forests: Northern Forest-industrial Regimes in the Age of Globalization (pp. 255-284). Ashgate: Alfershot.

Eloranta, J., Golson, E., Hedberg, P., \& Moreira, M. C. (Eds.) (2018). Small and Medium Powers in Global History: Trade, Conflicts, and Neutrality from the 18th to the 20th Centuries. New York: Routledge.

Entman, R.M. (2007). Framing Bias: Media in the Distribution of Power. Journal of communication, 57(1), 163-173.

FANC (2014). Ollako vaiko eikö olla: Askelkuvio biotaloudelle. https:// www.sll.fi/app/uploads/2018/10/biotalous_raportti_sll_2014.pdf. Accessed 15 Nov 2019.

FCCP (2015). Metsien hyödyntämisen ilmastovaikutukset ja hiilinielujen kehittyminen. https://www.ilmastopaneeli.fi/wp-content/uploads/2018/10/ Metsien-hyodyntamisen-ilmastovaikutukset-ja-hiilinielujen-kehittyminen. pdf. Accessed 15 Nov 2019.

FCCP (2018). Ilmastopaneelin näkemykset pitkän aikavälin päästövähennystavoitteen asettamisessa huomioon otettavista seikoista. https:/www.ilmast opaneeli.fi/wp-content/uploads/2018/10/Ilmastopaneelin-muistio_hyvaksy tty_4.6.2018.pdf. Accessed 15 Nov 2019.

FCCP (2019). Skenaarioanalyysi metsien kehitystä kuvaavien mallien ennusteiden yhtäläisyyksistä ja eroista. https://www.ilmastopaneeli.fi/wpcontent/uploads/2019/02/Ilmastopaneeli_mets\%C3\%A4mallit_raportti_ 180219.pdf. Accessed 15 Nov 2019.

Finnish Bioeconomy Strategy (2014). Kestävää kasvua biotaloudesta Suomen biotalousstrategia. https://biotalous.fi/wp-content/uploads/2014/ 07/Julkaisu_Biotalous-web_080514.pdf. Accessed 15 Nov 2019.

Goven, J., \& Pavone, V. (2015). The Bioeconomy as Political Project: A Polanyian Analysis. Science, Technology, \& Human Values, 40(3), 302-337. Harjanne, A., \& Korhonen, J.M. (2019). Abandoning the Concept of Renewable Energy. Energy Policy, 127, 330-340. 
Harjuniemi, T. (2019). Reason over Politics: The Economist's Historical Framing of Austerity. Journalism Studies, 20(6), 804-822.

Hukkinen, J.I., Kotiaho, J.S., \& Vesala, T. (2017). Kirje, joka nostatti myrskyn [A Letter That Caused a Storm]. Alue ja Ympäristö, 46 (1), 46-51.

Huttunen, R. (Ed.) (2017). Valtioneuvoston selonteko kansallisesta energia-ja ilmastostrategiasta vuoteen 2030. Helsinki: Publications of the Ministry of Economic Affairs and Employment 4/2017. http://julkaisut.valtioneuvosto. fi/bitstream/handle/10024/79189/TEMjul_4_2017_verkkojulkaisu.pdf?seq uence $=1$ \&isAllowed $=y$. Accessed 15 Nov 2019.

Kotilainen, J., \& Rytteri, T. (2011). Transformation of Forest Policy Regimes in Finland Since the 19th Century. Journal of Historical Geography, 37(4), 429-439.

Kröger, M., \& Raitio, K. (2017). Finnish Forest Policy in the Era of Bioeconomy: A Pathway to Sustainability? Forest policy and Economics, 77, 6-15.

Letter from Scientists (2018). Letter from Scientists to The EU Parliament Regarding Forest Biomass. http://www.pfpi.net/wp-content/uploads/2018/ 04/UPDATE-800-signatures_Scientist-Letter-on-EU-Forest-Biomass.pdf.

Accessed 15 Nov 2019.

Meyer, R. (2017). Bioeconomy Strategies: Contexts, Visions, Guiding Implementation Principles and Resulting Debates. Sustainability, 9(6), 1031.

Peltomaa, J. (2018). Drumming the Barrels of Hope? Bioeconomy Narratives in the Media. Sustainability, 10(11), 4278.

Public Statement (2017). Public Statement of 68 Researchers. https://bios.fi/ publicstatement/publicstatement240317.pdf. Accessed 15 Nov 2019.

Rockström, J., Gaffney, O., Rogelj, J., Meinshausen, M., Nakicenovic, N., \& Schellnhuber, H.J. (2017). A Roadmap for Rapid Decarbonization. Science, 355(6331), 1269-1271.

Searchinger, T.D., Beringer, T., Holtsmark, B., Kammen, D.M., Lambin, E.F., Lucht, W., \& van Ypersele, J.P. (2018). Europe's Renewable Energy Directive Poised to Harm Global Forests. Nature communications, 9(1), 3741.

Sievänen, R., Salminen, O., Lehtonen, A., Ojanen, P., Liski, J., Ruosteenoja, K., et al. (2014). Carbon Stock Changes of Forest Land in Finland Under Different Levels of Wood Use and Climate Change. Annals of forest science, 71(2), 255-265.

Siiskonen, H. (2007). The Conflict Between Traditional and Scientific Forest Management in 20th Century Finland. Forest Ecology and Management, 249(1-2), 125-133. 
Soimakallio, S., Saikku, L., Valsta, L., \& Pingoud, K. (2016). Climate Change Mitigation Challenge for Wood Utilization. The Case of Finland. Environmental Science \& Technology, 50(10), 5127-5134.

Vadén, T., Majava, A., Toivanen, T., Järvensivu, P., Hakala, E., \& Eronen, J.T. (2019). To Continue to Burn Something? Technological, Economic and Political Path Dependencies in District Heating in Helsinki, Finland. Energy Research \& Social Science, 58, 101270.

Open Access This chapter is licensed under the terms of the Creative Commons Attribution 4.0 International License (http://creativecommons.org/ licenses/by/4.0/), which permits use, sharing, adaptation, distribution and reproduction in any medium or format, as long as you give appropriate credit to the original author(s) and the source, provide a link to the Creative Commons license and indicate if changes were made.

The images or other third party material in this chapter are included in the chapter's Creative Commons license, unless indicated otherwise in a credit line to the material. If material is not included in the chapter's Creative Commons license and your intended use is not permitted by statutory regulation or exceeds the permitted use, you will need to obtain permission directly from the copyright holder. 